\title{
Alternate wetting and drying (AWD) technology: A way to reduce irrigation cost and ensure higher yields of Boro rice
}

\author{
Mrinmoy Guha Neogi ${ }^{1}$, A. K. M. Salah Uddin ${ }^{2,}$ M. Taj Uddin ${ }^{3}$ and Muhammad Abdul Hamid \\ Miah $^{1}$ \\ ${ }^{1}$ IRRI, Banani, Dhaka; ${ }^{2}$ FAO, Dhanmondi, Dhaka and ${ }^{3}$ Department of Agricultural Economics, Bangladesh Agricultural \\ University, Mymensingh-2202, Bangladesh
}

\begin{tabular}{l}
\hline ARTICLE INFO \\
\hline Article history: \\
Received: 31 October 2017 \\
Accepted: 09 April 2018 \\
\hline Keywords: \\
AWD, irrigation, groundwater, \\
pump owner, STW \\
\hline
\end{tabular}

Correspondence:

M. Taj Uddin

(tajbau@yahoo.com)

\begin{abstract}
Massive extraction of groundwater for boro rice is the main cause of declining groundwater tables, especially in Rangpur Division, which is now a burning issue at the national level. It is now scientifically proven that rice is not a water-loving plant, but rather a water-tolerant plant. AWD can save water and energy, where both farmers and pump-owners can save around $30 \%$ of their irrigation water requirements. In Bangladesh around 4.8 million hectares of land are brought under irrigated boro rice where AWD technology can be utilized. With introduction of AWD technology, a savings of electricity costs equivalent to 5 billion Tk. or fuel cost equivalent to 7 billion Tk. will be incurred at the national level. Hence, the implementation of AWD technology will have major impacts at the farm and national levels, which can reduce irrigation cost significantly, thus saving foreign currency, as well as reducing excessive use of ground water.
\end{abstract}

\section{Introduction}

In Bangladesh, rice is the staple food, where three rice growing seasons are existing; the "aus" in early monsoon season, "aman" during the monsoon and "boro" in the dry season. Boro rice is normally sown in November-December and harvested in late April to May under fully irrigated condition. Due to the introduction of Shallow Tube Well (STW), the boro rice cultivation in Bangladesh increased from 9\% of the total rice area in the country in 1966-67 to $60 \%$ in 2010 . This expansion required massive use of irrigation water, causing ground water tables to decline in northern Bangladesh at the rate of $4 \mathrm{~cm}$ per year, and thus water scarcity is increasing. Right now, farmers are paying around $30 \%$ of the total rice production cost for irrigation purposes in northern Bangladesh. It was estimated that 3,400 liters of water were being used to produce $1 \mathrm{~kg}$ of rice. Physiologically, irrigated rice does not necessarily require this amount of water (Kurschner et al., 2010).

In Bangladesh, normally STW pump owners provide water on what is called "serial" system. The pump owner independently decides on the entire irrigation schedule under a fixed cost. The owner starts to irrigate farmers' lands in his command area from one side and continue irrigating in serial manner from one plot to the adjacent one until he reaches the last plot. In most cases, farmers try to store water as much as possible during his irrigation turn. Besides, most farmers believe that standing water in paddy field at all the stages is required to ensure higher yield. Research results have shown that standing water is recommended at transplanting to control weeds and during flowering and subsequent grain filling stage to avoid water stress (Rice fact sheet, IRRI).

The International Rice Research Institute (IRRI) has developed the Alternate Wetting and Drying (AWD) technology as a water saving strategy for rice production. AWD method can save water by about 38\% without adversely affecting rice yields (Rejesus, R.M et al., 2011). This method increases water productivity by $16.9 \%$ compared with continuously flood irrigation (Tan, X et al., 2013). AWD can dramatically reduce the concentration of arsenic in harvested rice grains (Price, A.H. et al., 2013). Through AWD, the water level in the soil is monitored by a perforated plastic tube or plastic water bottle, which is inserted into the rice field (Fig. 1). As the water level drops below the soil surface, the soil is still saturated and thus water is still available for the rice plant. Hence, the water level in the field can drop to $15 \mathrm{~cm}$ below the soil surface during the vegetative stage, without causing yield losses. However, AWD requires irrigation when the water levels drop below $15 \mathrm{~cm}$ below the soil surface (Tuong, 2007). 


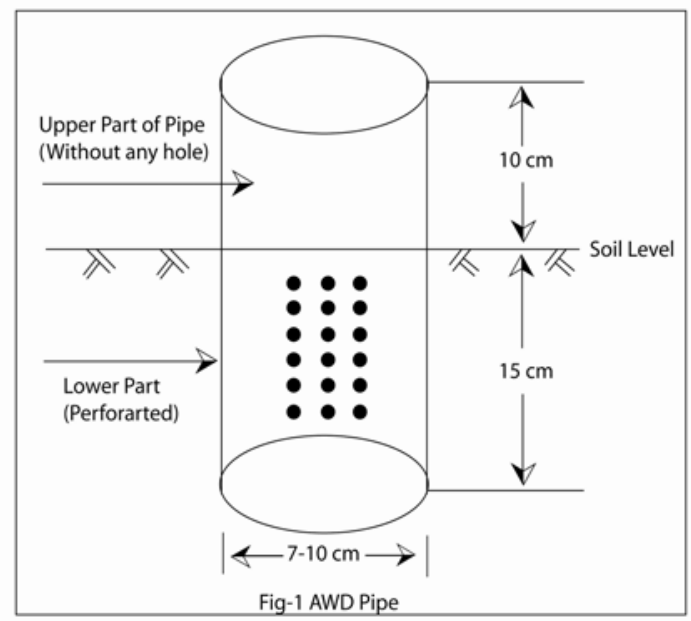

\section{Materials and Methods}

With the technical assistance of IRRI, RDRS Bangladesh (a NGO) implemented AWD technology in farmers' field in all districts of Rangpur Division, during the boro rice season. This AWD technology piloted in 109 farmers' field in 2013-14, where farmers cultivated boro rice with reduced number of irrigations (11 irrigations instead of 17) and produced almost the same yield as in the case without AWD system (Table - 1). This reduction in irrigation frequency saved $35 \%$ of the irrigation cost. However, it was observed that weed infestation was more serious in AWD plots, which increased the cost of hired laborer for weeding (Table 1).

Table 1. Performance of AWD technology in comparison with traditional farmers' practice in 2013-14 at Rangpur. Values are means across 109 farmers

\begin{tabular}{ccccccc}
\hline $\begin{array}{c}\text { Land } \\
\text { (decimals) }\end{array}$ & $\begin{array}{c}\text { Irrigation } \\
\text { (No.) }\end{array}$ & $\begin{array}{c}\text { Weeding } \\
\text { (No.) }\end{array}$ & $\begin{array}{c}\text { Labour cost for } \\
\text { weeding (Tk.) }\end{array}$ & $\begin{array}{c}\text { Yield } \\
\text { (kg) }\end{array}$ & $\begin{array}{c}\text { Yield } \\
\text { (t/ha) }\end{array}$ & $\begin{array}{c}\text { Gross income from 10 } \\
\text { Decimals (Tk) }\end{array}$ \\
\hline $\begin{array}{c}\text { Traditional-full irrigation } \\
10\end{array}$ & 17 & 2 & 300 & 162 & 4.00 & 3564 \\
$\begin{array}{c}\text { AWD } \\
10\end{array}$ & 11 & 2 & 450 & 157 & 3.87 & \\
\hline
\end{tabular}

Although the number of irrigations was reduced significantly (30\%) and the corresponding irrigation cost was reduced by 35\%, the benefits went to the pump owners due to the fixed-rate arrangement system between pump owner and farmers set at the beginning of the season. In this system, farmers pay a fixed cost per unit area regardless of the number of irrigations during the season.

On the other hand, farmers faced more serious weed problems under AWD system, which resulted in increased laborer cost for weeding. Due to these excessive weed infestations under AWD system, farmers probably harvested less yields compared to non-AWD system. However, this method can even increase grain yield because of enhancement in grain-filling rate, root growth and remobilization of carbon reserves from vegetative tissues to grains (Tuong, T et al., 2015, Yang, J et al., 2007, Zhang, $\mathrm{H}$ et al 2008).

Based on what was learned from this first set of trials, the AWD technology was again piloted in 2014-15, but with herbicide use in AWD plots. Pump owners were also convinced to adopt the technology along with farmers. During the training period, the pump owner agreed to apply irrigation water as needed based on the guidelines of AWD technology. It was also agreed that if the irrigation frequency was reduced by $30 \%$, the pump owners should charge $20 \%$ less than the conventional rate. Under these agreed condition, 36 blocks were involved, with 36 pump owners in Rangpur Division, with a total of 324 farmers in AWD and use of herbicides. Results were summarized in (Table 2).

Table 2. Performance of rice under AWD technology with herbicide compared with AWD technology without herbicide at Rangpur Division in 2014-15. Data are means of 324 farmers from 36 blocks

\begin{tabular}{ccccccc}
\hline $\begin{array}{c}\text { Land } \\
\text { (Decimals) }\end{array}$ & $\begin{array}{c}\text { Irrigation } \\
\text { (No.) }\end{array}$ & $\begin{array}{c}\text { Weeding } \\
\text { (No.) }\end{array}$ & $\begin{array}{c}\text { Labour cost for } \\
\text { weeding (Tk.) }\end{array}$ & $\begin{array}{c}\text { Yield } \\
\text { (kg) }\end{array}$ & $\begin{array}{c}\text { Yield } \\
\text { (t/ha) }\end{array}$ & $\begin{array}{c}\text { Gross income } \\
\text { (Tk) }\end{array}$ \\
\hline $\begin{array}{c}\text { Traditional method } \\
7\end{array}$ & 11 & 2 & 287 & 115 & 4.1 & 2875 \\
$\begin{array}{c}\text { AWD system* } \\
7\end{array}$ & $\begin{array}{c}7.5 \\
\begin{array}{c}\text { AWD system with Herbicide** } \\
7\end{array}\end{array}$ & 2 & 362 & 111 & 4.0 & 2775 \\
\hline
\end{tabular}

*Average gain from AWD system alone: Tk. 300 (saved from irrigation) - Tk. 75 (extra cost for weeding - Tk. 100 (reduced yield). Total gain $=$ Tk. 125

**Average gain from AWD with with herbicide: Tk. 300 (saved from irrigation) + Tk. 187 (saved from weeding) - Tk.80 (cost of herbicide). Total gain $=$ Tk. 407. 


\section{Results and Discussion}

These studies showed that, in AWD-herbicide system, both farmers and pump owners were in a win-win situation, as both are getting higher benefits compared with the traditional irrigation system as well as with the AWD system with hand weeding. Pump owners can save 3.5 irrigations from both AWD and AWD with herbicide systems. The farmers can also save Tk. 300 from the irrigation cost of 7 decimals of land under AWD with herbicide system. Moreover, AWD with herbicide system saved Tk. 187 from weeding and resulting in similar yield as the traditional system, with only Tk. 80 required for herbicides, resulting in a total gain of Tk. 407 from 7 decimals of land.

Farmers can save Tk. 300 from irrigation costs of the same 7 decimals of land under AWD system, but lose Tk. 75 for weeding and Tk. 100 from yield reduction due to weeds. So their total gains become Tk. 125 when using only AWD system. Although, AWD with herbicide system assured higher benefit, farmers need to be trained to ensure safe use of herbicides. It was found that use of AWD method contributed an eventual profit of Tk 4224/ha for adopting the newly emerged irrigation technique instead of using the conventional irrigation (Shahe Alam, M et al., 2009).

\section{Savings in fuel and electricity}

Currently, the nation is facing a serious scarcity of energy as the demand largely exceeded local supply and import sources. Under this situation, there are two options - one is to reduce the wastage of energy and the other is to replace present dependence on fossil fuel with renewable energy sources such as solar energy or biogas.

The largest sectors of people in the country are using non-renewable energy (e.g. electricity, fuel, etc.) for rice cultivation during boro season, where the government provides subsidy to boost and sustain production. This also resulted in misuse of these resources, basically because farmers' are not aware of actual requirements of irrigation for rice cultivation, coupled with the over exploitation by pump owners.

It is now evident from this study that, AWD system can help the nation to minimize the waste of energy and save significantly on these non-renewable resources. The following table provides an estimate of the energy usage under different irrigation systems. The data showed that a total of Tk. 1470 million could be saved annually only from Rangpur Division as a consequence or reduced diesel usage. This also results in reduction in foreign currency needs to import fuel. AWD can reduce the cost of irrigation by reducing pumping costs and fuel consumption (Lampayan et al., 2015). The use of less irrigation was associated with the reduction of irrigation cost by 12 to 15\% implying a clear advantage of AWD irrigation to the resource poor farmers (Shahe Alam, M et al., 2009).

Table 3. Number of irrigations and energy saving under AWD system. Data are averages of 2009-10 and 2014-15 seasons

\begin{tabular}{lccccc}
\hline System & $\begin{array}{c}\text { Irrigation } \\
\text { (No.) }\end{array}$ & $\begin{array}{c}\text { Irrigation cost/ha } \\
\text { (Tk.) for diesel only }\end{array}$ & $\begin{array}{c}\text { Diesel } \\
\text { saving in } \\
\text { Tk/ha. }\end{array}$ & $\begin{array}{c}\text { Total boro area in } \\
\text { Rangpur Division } \\
\text { (ha) }\end{array}$ & $\begin{array}{c}\text { Estimated savings from } \\
\text { reductions in diesel usage } \\
\text { (Tk.) }\end{array}$ \\
\hline Traditional & 14 & 385 X 14 = 5,390 & - & 804,206 & - \\
AWD & 9.25 & 385 X $9.25=3561$ & 1829 & 804,206 & 1470 Million \\
AWD with herbicide & 9.25 & 385 X 9.25 = 3561 & 1829 & 804,206 & 1470 Million \\
\hline
\end{tabular}

Despite these advantages, AWD has its limitation; the most important is the availability of labor in time for weeding and also careful monitoring of water level to avoid water stress.

\section{Recommendations}

- $\quad$ Pump owners should be considered as the most important client along with farmers in STW/DTW command area.

- AWD technology should be employed in a cluster area along with a pump owner and all farmers the command area. Sufficient training and awareness of both pump owners and farmers.

- Proper installation of plastic tubes within 10-15 days of transplanting.

- A clear understanding or agreement between pump owners and farmers about reduced payment system under AWD technology is the pre-condition to sustain and popularize the technology.

- Proper application of AWD based on crop stage, e.g. re-irrigation when ground water reaches $15-20 \mathrm{~cm}$ below the soil surface, and maintaining standing water of $5 \mathrm{~cm}$ during flowering stage.

- Then continue AWD cycles after flowering through ripening stage of the crop.

\section{Conclusion}

Massive extraction of groundwater for boro rice is the main cause of declining groundwater tables, especially in Rangpur Division, which is now a burning issue at the national level. It is now scientifically proven that rice is not a water-loving plant, but rather a water-tolerant plant. AWD can save water and energy, where both farmers and pump-owners can save around $30 \%$ of their irrigation water requirements. 
In Bangladesh around 4.8 million hectares of land are brought under irrigated boro rice where AWD technology can be utilized. With introduction of AWD technology, a savings of electricity costs equivalent to Tk. 5 billion or fuel cost equivalent to Tk. 7 billion will be incurred at the national level. Hence, the implementation of AWD technology will have major impacts at the farm and national levels, which can reduce irrigation cost significantly, thus saving foreign currency, as well as reducing excessive use of ground water.

\section{References}

Kurschner, E., Henschel, C., Hilderbrandt, T., Julich, E., Leineweber, M., Paul, C. (2010). Water saving in rice productionDissemination, Adoption and Short Term Impacts of Alternate Wetting and Drying (AWD) in Bangladesh: SLE Publication Series - S241. Humboldt University, Berlin.

Lampayan, R.M., Rejesus, R.M., Singleton, G.R., Bouman, B.A., 2015. Adoption and economics of alternate wetting and drying water management for irrigated lowland rice. Field Crops Research 170, 95-108.

Price, A.H., Norton, G.J., Salt, D.E., Ebenhoeh, O., Meharg, A.A., Meharg, C., Islam, M.R., Sarma, R.N., Dasgupta, T., Ismail, A.M. 2013. Alternate wetting and drying irrigation for rice in Bangladesh: Is it sustainable and has plant breeding something to offer? Food and Energy Security 2, 120-129.
Rice Fact sheet - Saving Water: Alternate Wetting Drying (AWD): Rice Science for a Better World). IRRI. SWIM. 1997. Water-saving techniques in rice irrigation. Report of the SWIM Mission to Guilian Prefecture, Guangxi Region, China, 25-30 May 1997.

Rejesus, R.M., Palis, F.G., Rodriguez, D.G.P., Lampayan, R.M., Bouman, B.A., 2011. Impact of the alternate wetting and drying (AWD) water-saving irrigation technique: evidence from rice producers in the Philippines. Food Policy 36, 280-288.

Shahe Alam, M., Islam, M. S., Salam, M. A., Islam M. A. (2009). Economics of Alternate Wetting and Drying Method of Irrigation: The Agriculturists 7(1\&2): 82-89.

Tuong, T.P. (2007). Alternate Wetting and Drying Irrigation (AWD): A technology for water saving in rice production: Paper presented at the Crop Cutting Ceremony, BADC Farm, Madhopur, Tangail, Bangladesh, 14 May 2007.

Tan, X., Shao, D., Liu, H., Yang, F., Xiao, C., Yang, H., 2013. Effects of alternate wetting and drying irrigation on percolation and nitrogen leaching in paddy fields. Paddy and Water Environment 11, 381-395.

Tuong, T., Bouman, B., Mortimer, M., 2005. More rice, less waterintegrated approaches for increasing water productivity in irrigated rice-based systems in Asia. Plant Prod. Sci 8, 231241.

Yang, J., Liu, K., Wang, Z., Du, Y., Zhang, J., 2007. Water- saving and high-yielding irrigation for lowland rice by controlling limiting values of soil water potential. Journal of Integrative Plant Biology 49, 1445-1454.

Zhang, H., Zhang, S., Yang, J., Zhang, J., Wang, Z., 2008. Postanthesis moderate wetting drying improves both quality and quantity of rice yield. Agronomy Journal 100, 726734. 